Article

\title{
Antioxidant and Cytotoxic Activities of Centella asiatica (L) Urb.
}

\section{Frederico Pittella ${ }^{1}$, Rafael C. Dutra ${ }^{1}$, Dalton D. Junior ${ }^{2}$, Miriam T. P. Lopes ${ }^{2}$ and Nádia R.} Barbosa $^{1, *}$

1 Departamento de Alimentos e Toxicologia, Faculdade de Farmácia e Bioquímica, Universidade Federal de Juiz de Fora, Martelos, CEP 36036-330, Juiz de Fora, MG, Brazil; E-Mail: fredpittella@gmail.com (F.P.)

2 Laboratório de Substâncias Antitumorais, Instituto de Ciências Biológicas, Universidade Federal de Minas Gerais, CEP 31270-901, Belo Horizonte, MG, Brazil;

E-Mail: mtpl@icb.ufmg.br (M.T.P.L.)

* Author to whom correspondence should be addressed; E-Mail: nadiafox@gmail.com.

Received: 26 July 2009 / Accepted: 26 August 2009 / Published: 26 August 2009

\begin{abstract}
In the present study, the phenolic (Folin-Dennis) and flavonoid (colorimetric assay) constituents, antioxidant [2,2-diphenyl-2-picrylhydrazyl hydrate (DPPH) assay] and cytotoxic activities of an aqueous extract (AE) of Centella asiatica leaves were investigated. The aqueous extract $(50 \mathrm{~g} / \mathrm{L})$ was obtained by infusion followed by cold maceration for $24 \mathrm{~h}$. The levels of phenolic and flavonoid compounds were $2.86 \mathrm{~g} / 100 \mathrm{~g}$ and $0.361 \mathrm{~g} / 100 \mathrm{~g}$, respectively. The AE showed elevated DPPH scavenging activity, with an $\mathrm{IC}_{50}$ value of $31.25 \mu \mathrm{g} / \mathrm{mL}$. The $\mathrm{AE}$ had a promising activity against mouse melanoma $\left(\mathrm{B}_{16} \mathrm{~F}_{1}\right)$, human breast cancer (MDA MB-231) and rat glioma $\left(\mathrm{C}_{6}\right)$ cell lines, with $\mathrm{IC}_{50}$ values of $698.0,648.0$ and $1000.0 \mu \mathrm{g} / \mathrm{mL}$, respectively. A positive correlation was established between the level of flavonoids, antioxidant and antitumor activities.
\end{abstract}

Keywords: Centella asiatica; Umbelliferae; phenolic constituents; DPPH; cytotoxic 


\section{Introduction}

Aging is a natural process which is related to several morphological and biochemical changes that happens from maturity to senescence, making the organism vulnerable to diseases and toxicity, and eventually leading to cellular death. According to the hypothesis of oxidative stress on aging, the loss of functional capacity associated to senescence comes from accumulation of molecular oxidative damages [1] brought about by (toxic) free radicals produced during normal breathing. Free radicals were previously reported as being capable of damaging a lot of cellular components such as proteins, lipids and DNA [2].

To protect the cells from oxidative damages by oxidants, produced during oxygen methabolism, an antioxidant system is used by aerobic organisms. The main antioxidant agents such as superoxide dismutase (SOD), catalase, glutathione peroxidase (GSH-Px), glutathione, ascorbic acid and tocopherol are important for cellular protection, due to their ability to eliminate free radicals, such as reactive oxygen species (ROS) [3]. Nowadays, there is an increasing interest in the biochemical functions of natural antioxidant extracts from vegetables, fruits, and medicinal plants, which can become candidates to prevent oxidative damage, promoting health. The phenolic constituents found in vegetables have received considerable attention for being the main components of antioxidant activity, in spite of not being the only ones. The antioxidant activity of phenolic constituents has been attributed to its oxide-reduction properties, which play an important role in the adsorption or neutralization of free radicals [4].

Medicinal plants have been a useful source for the research of new biologically active compounds. Different approaches are used to select a plant for research, specially the ethno-medical data approach. Unfortunately, the ethno-medical data is not always completely reliable, since it is difficult to diagnosed cancer well. Apart from the medicinal effects of traditional herbs, exploratory researches have been made and a wide variety of new biological activities from traditional medicinal plants have recently been reported, including anticancer activity [5].

Centella asiatica (L) Urb., popularly known in Brazil as cairuçu-asiático, centelha, codagem and pata-de-mula [6], is a cosmopolitan member of the Umbelliferae family that presents pantropical distribution. It is a perennial herb that has been used for centuries in Ayurvedic medicine to treat several disorders, such as insanity, asthma, leprosy, ulcers and eczema and for wound healing $[7,8]$. Centella asiatica contains triterpene glycosides such as centellasaponin, asiaticoside, madecassoside and sceffoleoside [9], and also asiatic acid and madecassic acid [10,11]. Asiaticoside is the most abundant triterpene glycoside in the water extract and it is transformed into asiatic acid in vivo by hydrolysis. Although the asiatic acid has shown cytotoxic activity on fibroblast cells [12] and induces apoptosis in different sorts of cancer [13-18], to date no scientific report related the presence of phenolic compounds of Centella asiatica to cytotoxic activity. Consequently, we have focused on establishing a relationship between the total phenolic content and antioxidant activity with cytotoxic activity, evaluating the activity against cancer cell lines using aqueous extract (AE) obtained from Centella asiatica leaves. 


\section{Results and Discussion}

The AE showed a phenolic constituents level of $2.86 \mathrm{~g} / 100 \mathrm{~g}$. A recent report [19] showed that the method used quantifies mainly high-molecular weight tannins, such as hydrolysable tannin and other polyphenols that have a molecule of gallic acid in its structure, absorbing energy at the wavelength of $760 \mathrm{~nm}$. In fact, values found in this study are in agreement with the results published recently which obtained values ranging from 3.23-11.7 g/100 g for different parts of Centella asiatica [20].

The flavonoids level in the AE was $0.361 \mathrm{~g} / 100 \mathrm{~g}$. Flavonoids are highly polar molecules of low molecular weight which absorb energy around $420 \mathrm{~nm}$. Water is a polar extractant, so it will extract polar constituents, such as heterosides. In this work, water was used as liquid extractant and the level of flavonoids observed was high, suggesting that these flavonoid constituents might be in the heteroside form, since previous studies showed that flavonoids can be found in nature in the free state or in the form of glycosides [21,22].

The antioxidant activity of AE of Centella asiatica was evaluated by its ability to scavenge DPPH free radicals. The radical scavenging activity of the compounds can be measured by the decolorizing effect following the trapping of the unpaired electrons of DPPH. The AE showed a high antioxidant activity, with an $\mathrm{IC}_{50}$ value of $31.25 \mu \mathrm{g} / \mathrm{mL}$. Ascorbic acid and butylated hydroxytoluene (BHT) produced $\mathrm{IC}_{50}$ values of $2.50 \mu \mathrm{g} / \mathrm{mL}$ and $7.58 \mu \mathrm{g} / \mathrm{mL}$, respectively. Based on previous data, it is possible that the powerful antioxidant activity of polar extracts is due to the presence of substances with free hydroxyls [23]. In this context, flavonoids possess an ideal structure for the scavenging of free radicals, since they present a number of hydroxyls acting as hydrogen-donators which makes them important antioxidant agents [4,24].

The key role of phenolic compounds as free radical scavengers is emphasized in two important reports $[25,26]$. Antioxidative properties of essential oils and various extracts from many plants are of great interest in both academia and the food industry, since their possible use as natural additives has emerged from a growing trend to replace synthetic antioxidants by natural ones. Regarding this trend, the study of medicinal plant species has became of great importance, to find and test their bioactive compounds. The results indicate that AE obtained from Centella asiatica leaves showed the capacity to donate hydrogen; therefore they present DPPH scavenging activity. This activity might be due to the presence of phenolic and flavonic constituents detected in the samples. The results are in agreement with the recent study, which showed that Centella asiatica prevents the oxidative damage existing in several neuropathologies including stroke, Parkinson's disease and Alzheimer's disease, improving the antioxidant neurological state related to aging [27].

The cytotoxic activity $\left(\mathrm{IC}_{50}\right)$ of $\mathrm{AE}$ against four cancer cell lines and one normal cell line are shown in Table 1. The AE of Centella asiatica demonstrated a promising activity against human breast cancer (MDA-MB 231) and mouse melanoma $\left(\mathrm{B}_{16} \mathrm{~F}_{1}\right)(648.0$ and $698.0 \mu \mathrm{g} / \mathrm{mL}$, respectivelly), while that for rat glioma $\left(\mathrm{C}_{6}\right)$ the $\mathrm{IC}_{50}$ was $1,000.0 \mu \mathrm{g} / \mathrm{mL}$. On the other hand, the extract was not cytotoxic at the tested concentrations (up to $1,000.0 \mu \mathrm{g} / \mathrm{mL}$ ) towards the human lung carcinoma $\left(\mathrm{A}_{549}\right)$ and normal hamster kidney $(\mathrm{BHK}-21)$ cell lines. 
Table 1. Antitumor effects of AE of Centella asiatica against several cancer cell lines.

\begin{tabular}{llcc}
\hline & Cell lines & IC $_{50}(\mu \mathbf{g} / \mathbf{m L})$ & Taxol $^{\circledR}(\mu \mathbf{g} / \mathbf{m L})$ \\
\hline Tumoral & $\mathrm{B}_{16} \mathrm{~F}_{1}$ & 698.0 & $3.55 \times 10^{-6}$ \\
& MDA-MB 231 & 648.0 & $6.71 \times 10^{-6}$ \\
& $\mathrm{C}_{6}$ & 1000.0 & $3.43 \times 10^{-6}$ \\
& $\mathrm{~A}_{549}$ & $>1000.0$ & $6.03 \times 10^{-6}$ \\
Normal & $\mathrm{BHK} 21$ & $>1000.0$ & $1.06 \times 10^{2}$ \\
\hline
\end{tabular}

$\mathrm{N}=5 ; \mathrm{C}_{6}$ (rat glioma), MDA MB-231 (human breast cancer), $\mathrm{A}_{549}$ (human lung carcinoma), $\mathrm{B}_{16} \mathrm{~F}_{1}$ (mouse melanoma) and $\mathrm{BHK}-21$ (normal hamster kidney fibroblast).

The cytotoxic activity of AE shown in this work presented in the same range of cytotoxicity $(10-1,000 \mu \mathrm{g} / \mathrm{mL})$ towards the $\mathrm{B}_{16} \mathrm{~F}_{1}$, MDA-MB 231 and $\mathrm{C}_{6}$ cell lines demonstrated in studies with extracts of other plants with cytotoxic potential in South Korea [5], Tanzania [28], Italy and Jordan [29]. Another report [17] shows that the purified asiatic acid, also present in the AE, decreased the viability of MDA-MB 231 cells in a dose-dependent manner.

Moreover, the extract was not cytotoxic against the $\mathrm{A}_{549}$ (lung carcinoma) and BHK-21 (normal kidney cancer) cell lines. These results suggest a possible selectivity of the AE of Centella asiatica against some cancer cell lines, as observed for the cisplatin compounds, that are preferentially used for testicular [36] and ovarian cancer [37]. The selectivity of action could be related to the differences in morphology and physiology between tested cell lines, although this is not yet proven. These results are very encouraging, considering that most chemotherapeutic agents found on the market act both on tumor and normal cells [30] and cannot promote a specific treatment for the cancer without causing side effects as a result of damage to normal cells.

Although asiaticoside has not been reported in the scientific literature as a cytotoxic agent, the activity presented here may be related to its major presence in the extract, or even its performance in synergy with other constituents such as phenolic and flavonic constituents identified in this extract. Oxidative stress leads to the damage of membrane lipids, DNA, protein and cellular organelles, contributing to the development of cancer, early-aging, cardiovascular diseases, degenerative and neurological diseases and others. The phenolic constituents, especially the flavonoids, have high antioxidant capacity due to its properties of oxidation-reduction which plays an important role in the adsorption or neutralization of free radicals [4] showing raised biological protection. Since free radicals are involved in the establishment of cancer, the AE containing asiaticoside and other phenolic constituents can act reducing the number of free radicals (antioxidant activity), however at higher concentrations, promotes the cytotoxic effect, as observed in the results of cytotoxic assay.

\section{Experimental}

\subsection{General}

Leaves of Centella asiatica were collected in April 2006 from the campus of the Universidade Federal de Juiz de Fora (Minas Gerais, Brazil) and authenticated by Dr Fátima Regina Gonçalves Salimena from the Department de Botany, UFJF, Brazil. A voucher specimen ( $\mathrm{N}^{\mathrm{o}}$ 24.610) is deposited 
at the CESJ Herbarium of the Universidade Federal de Juiz de Fora (Minas Gerais, Brazil). Fresh plants were dried and used to prepare the aqueous extract (AE) as previously described [31]. Basically, the extract was prepared by infusion of Centella asiatica $(200 \mathrm{~g})$ in ultra pure water $(4 \mathrm{~L})$ followed by cold maceration for $24 \mathrm{~h}$. The solution was filtered and then freeze-dried to yield a residue that was stored at $-80^{\circ} \mathrm{C}$ until use.

A spectrophotometric method explained AOAC [32] was adapted for the phenolic content assay. The AE, was dissolved in methanol to obtain a concentration of $0.5 \mathrm{mg} / \mathrm{mL}$. Folin-Dennis reagent $(100 \mu \mathrm{L})$ was added to a test tube containing the extracts or fractions $(10 \mu \mathrm{L})$. Contents were mixed and a saturated sodium carbonate solution $(200 \mu \mathrm{L})$ was added to the tube. Volume was adjusted to $2 \mathrm{~mL}$ by the addition of $1.69 \mathrm{~mL}$ of distilled water and the contents were mixed vigorously. Tubes were allowed to stand at room temperature for $25 \mathrm{~min}$ and then centrifuged for $5 \mathrm{~min}$ at $2,435 \times$. . Absorbance of the supernatant was read at $760 \mathrm{~nm}$. A blank sample of extract was used for background subtraction. Tannic acid was used as standard for the construction of the calibration curve $(2-10 \mu \mathrm{g} / \mathrm{mL})$. The assay was carried out in triplicate.

The procedure used for the quantification of flavonoids is based on the reaction between the flavonoids and aluminum chloride forming a yellow colored complex that can be measured in a spectrophotometer at a wavelength of $420 \mathrm{~nm}$ [33]. Rutin was used as standard for the construction of the calibration curve $(2-30 \mu \mathrm{g} / \mathrm{mL})$. For the quantification of the flavonoids content in the AE, an aliquot of $4 \mathrm{~mL}$ of chloroform and $6 \mathrm{~mL}$ of distillated water was added to $10 \mathrm{~mL}$ of the previously obtained sample. The resulting solution was mixed and centrifuged for $3 \mathrm{~min}$ at 2,435× $\mathrm{g}$. Two milliliters of the aqueous phase was diluted to $25 \mathrm{~mL}$ with $10 \mathrm{~mL}$ of the reagent (pyridine, distilled water and aluminum chloride solution 17:80:3, v/v), $12.4 \mathrm{~mL}$ of a solution composed of water and dimethyl sulfoxide $(1: 2, \mathrm{v} / \mathrm{v})$ and $0.6 \mathrm{~mL}$ of glacial acetic acid and, soon after vortexing the reaction mixture, the tube was placed in the dark for $15 \mathrm{~min}$ and the absorbance was measured at a wavelength $420 \mathrm{~nm}$ against the reagent blank. The construction of the calibration curve and the preparation of the sample solutions of the hydroalcoholic extracts for reading were done in triplicate.

The radical scavenging activity was determined by the 2,2-diphenyl-2-picrylhydrazyl hydrate (DPPH) method [34]. The DPPH molecule is a stable-free radical by virtue of the delocalization of the spare electron over the molecule; this delocalization produces a deep violet color, characterized by an absorption band in ethanol or methanol solution centered at about $517 \mathrm{~nm}$. When a solution of DPPH is mixed with that of a substance, that can donate a hydrogen atom, this gives rise to the reduced form (diphenylpicrylhydrazine), with the loss of the violet color. An aliquot $(0.5 \mathrm{~mL})$ of ethanol solution containing of the AE obtained from leaves of Centella asiatica $(0.97-250 \mu \mathrm{g} / \mathrm{mL})$ was added to $1.5 \mathrm{~mL}$ of daily prepared ethanol DPPH solution $(0.05 \mathrm{mM})$. The optical density change at $517 \mathrm{~nm}$ was measured $30 \mathrm{~min}$ later by a spectrophotometer. A blank was used to remove the influence of the color of the sample. An ethanolic solution of DPPH was used as negative control. Ascorbic acid and butylated hydroxytoluene (BHT) were used as reference drugs, at the same concentrations $(0.97-250 \mu \mathrm{g} / \mathrm{mL})$ as was used for the sample. Results were expressed as mean inhibiting concentration $\left(\mathrm{IC}_{50}\right) . \mathrm{IC}_{50}$ parameter is defined as the concentration $(\mu \mathrm{g} / \mathrm{mL})$ of substrate that causes $50 \%$ loss of DPPH activity (color) and it was calculated by using the following equation: $\mathrm{IC}_{50}(\%)=100 \times\left(\mathrm{A}_{0}-\mathrm{A}_{\mathrm{s}}\right) / \mathrm{A}_{0}$, where $\mathrm{A}_{0}$ and $\mathrm{A}_{\mathrm{s}}$ are the values for the absorbance of the negative control and the absorbance of the sample, respectively. Tests were carried out in triplicate. 
The cytotoxicity assay was evaluated with several tumoral cell lines. To represent more than one embryonic origin cell line, the following cell lines were used in this study: mouse melanoma $\left(\mathrm{B}_{16} \mathrm{~F}_{1}\right)$, human breast cancer (MDA MB-231), rat glioma $\left(\mathrm{C}_{6}\right)$, human lung carcinoma $\left(\mathrm{A}_{549}\right)$ and normal hamster baby kidney line (BHK-21). The MDA-MB 231 and $\mathrm{B}_{16} \mathrm{~F}_{1}$ were provided by Dr Ricardo Brentani (Instituto Ludwig de Pesquisa Contra o Câncer, São Paulo, Brazil). The BHK-21 (Baby Hamster Kidney), was provided by CPAFA (Centro Pan-americano de Febre Aftosa, Rio de Janeiro, Brazil). The $\mathrm{A}_{549}$ and $\mathrm{C}_{6}$ were provided by Dr. Hugo Armelin (Instituto de Química da Universidade de São Paulo, São Paulo, Brazil).

The cytotoxic potential was evaluated using the MTT assay [35]. Cells ( $10^{3}$ cells/well) were seeded in RPMI 1640 (Sigma Chemical Co.) medium supplemented with 10\% fetal bovine serum (FBS) in 96-well culture plates (Falcon, NJ, USA) and were incubated in a humidified atmosphere with 5\% $\mathrm{CO}_{2}, 37{ }^{\circ} \mathrm{C}$, for $24 \mathrm{~h}$ until total adhesion to surface. The medium was replaced with fresh supplemented medium containing different concentrations of $\mathrm{AE}$ of Centella asiatica $(0.1-1000 \mu \mathrm{g} / \mathrm{mL})$. Cells were then incubated at $37^{\circ} \mathrm{C}$ for $48 \mathrm{~h}$. After this time, the medium was newly refreshed with the same concentration of $\mathrm{AE}$ and the plate was incubated again for $72 \mathrm{~h}$. After incubation time, $10 \mu \mathrm{L}$ of a $5 \mathrm{mg} / \mathrm{mL}$ stock solution of MTT in PBS was added to each well containing the cells and incubated again for $4 \mathrm{~h}$. Then, the supernatant without cells was aspirated from each well and $100 \mu \mathrm{L}$ of DMSO was added to dissolve the dark blue formazan crystals resulting from MTT reduction by homogenization in plate shaker. The extent of MTT reduction to formazan within cells was measured by absorbance at $600 \mathrm{~nm}$ using a scanning microplate reader (Stat Fax-2100, Awareness Tecn.). Cultures used as controls did not receive extract.

The percentages of inhibition of cell viability were calculated with the values of viability of cell exposed to the AE and with non-exposed cells, using the software GraphPad Prisma 3.0 (GraphPad Software, Inc.). The $50 \%$ inhibitory concentrations for cellular population $\left(\mathrm{IC}_{50}\right)$ were calculated by linear regression (SigmaPlot 10.0, Systat Software, Inc.) in the interval of the corresponding concentrations to the curve of MTT metabolization vs. log of the used concentrations.

\section{Conclusions}

The results of this study demonstrate the antioxidant capacity of the AE of Centella asiatica related to its phenolic and flavonoid constituents and its antitumor potential against cancer cell lines. The results suggest that the potent antioxidant and antitumor activity are justified by the high concentration of phenolic constituents, mainly the flavonoids present in the extract. This study indicates that bioactive molecules present in Centella asiatica can be used as a prototype for development of new drugs and/or as a source of antioxidant and antitumor pharmaceutical raw material.

\section{Acknowledgments}

The authors are grateful to Professor Dr. Daniel Sales Pimenta, for the orientation on the preparation of AE of Centella asiatica. This work was supported by Coordenação de Aperfeiçoamento de Pessoa de Nível Superior (CAPES). F.P. and R.C.D. are post-graduate students in genetics/biotechnology receiving grants from CAPES and UFJF, respectively. 


\section{References}

1. Sohal, R.S.; Mockett, R.J.; Orr, W.C.; Holbrook, N.J. Mechanisms of aging: An appraisal of the oxidative stress hypothesis. Free Rad. Biol. Med. 2002, 33, 575-586.

2. Hamilton, M.L.; Remmen, H.V.; Drake, J.A.; Yang, H.; Guo, Z.M.; Kewitt, K.; Walter, C.A.; Richardson, A. Does oxidative damage to DNA increase with age? Proc. Nat. Acad. Sci. USA 2001, 98, 10469-10474.

3. Young, I.S.; Woodside, J.V. Antioxidants in health and disease. J. Clin. Pathol. 2001, 54, 176186.

4. Basile, A.; Ferrara, L.; Del Pozzo, M.; Mele, G.; Sorbo, S.; Bassi, P.; Montesano, D. Antibacterial and antioxidant activities of ethanol extract from Paullinia cupana Mart. J. Ethnopharmacol. 2005, 102, 32-36.

5. Yoo, H.H.; Park, J.H.; Kwon, S.W. In vitro cytotoxic activity of some korean medicinal plants on human cancer cell lines: Enhancement in cytotoxicity by heat processing. Phytother. Res. 2007, 21, 900-903.

6. Coelho, M.G.; Cheddier, L.M.; Scio, E.; Pimenta, D.S. Alterações morfoanatômicas e químicas em Centella erecta (Linn. F.) Fernand., relacionadas à luminosidade e sazonalidade. In Proceedings of Livro de resumos XI Seminário Mineiro de Plantas Medicinais e II ${ }^{\underline{a}}$ Jornada de Farmácia de Diamantina; Diamantina, Brazil, 2005; pp. 81-82.

7. Handa, S.S.; Deepak, M.; Mangal, A.K. Centella asiatica. In Indian Herbal Pharmacopoeia, Indian Drug Manufacture; Mumbai and Regional Res. Lab.: Jammu-Tawi, India, 1988; pp. 47-55.

8. Veerendrakumar, M.H.; Gupta, Y.K. Effect of different extracts of Centella asiatica on cognition and markers of oxidative stress in rats. J. Ethnopharmacol. 2002, 79, 253-260.

9. Matsuda, H.; Morikawa, T.; Ueda, H.; Yoshikawa, M. Medicinal foodstuffs. XXVII. Saponin constituents Gotu Kola (2): Structures of new ursane- and oleanane-type triterpene oligoglycosides, centellasaponin B, C, and D, from Centella asiatica cultivated in Sri Lanka. Chem. Pharm. Bull. 2001, 49, 1368-1371.

10. Inamdar, P.K.; Yeole, R.D.; Ghogare, A.B.; de Souza, N.J. Determination of biologically active constituents in Centella asiatica. J. Chromatogr. A. 1996, 742, 127-130.

11. Bonfill, M.; Mangas, S.; Cusidó, R.M.; Osuna, L.; Piñol, M.T.; Palazón, J. Identification of triterpenoid compounds of Centella asiatica by thin-layer chromatography and mass spectrometry. Biom. Chromatogr. 2006, 20, 151-153.

12. Coldren, C.D.; Hashim, P.; Ali, J.M.; Oh, S.K.; Sinskey, A.J.; Rha, C. Gene expression changes in the human fibroblast induced by Centella asiatica triterpenoids. Planta Med. 2003, 69, 725-732.

13. Babu, T.D.; Kuttan, G.; Padikkala, J. Cytotoxic and antitumour properties of certain taxa of Umbelliferae with special reference to Centella asiatica (L.) Urban. J. Ethnopharmacol. 1995, 48, 53-57.

14. Gurfinkel, D.M.; Chow, S.; Hurren, R.; Gronda, M.; Henderson, C.; Berube, C.; Hedley, D.W.; Schimmer, A.D. Disruption of the endoplasmic reticulum and increases in cytoplasmic calcium are early events in cell death induced by the natural triterpenoid Asiatic acid. Apoptosis 2006, 11, 1463-1471. 
15. Park, B.C.; Bosire, K.O.; Lee, E.S.; Lee, Y.S.; Kim, J.A. Asiatic acid induces apoptosis in SKMEL-2 human melanoma cells. Cancer Lett. 2005, 218, 81-90.

16. Cho, C.W.; Choi, D.S.; Cardone, M.H.; Kim, C.W.; Sinskey, A.J.; Rha, C. Glioblastoma cell death induced by asiatic acid. Cell Bio. Toxicol. 2006, 22, 393-408.

17. Hsu, Y.L.; Kuo, P.L.; Lin, L.T.; Lin, C.C. Asiatic acid, a triterpene, induces apoptosis and cell cycle arrest through activation of extracellular signal-regulated kinase and p38 mitogen-activated protein kinase pathways in human breast cancer cells. J. Pharmacol. Experim. Therap. 2005, 313, 333-344.

18. Park, B.C.; Paek, S.H.; Lee, Y.S.; Kim, S.J.; Lee, E.S.; Choi, H.G.; Yong, C.S.; Kim, J.A. Inhibitory effects of asiatic acid on 7,12-dimethylbenz $[\alpha]$ anthracene and 12-Otetradecanoylphorbol 13-acetate-induced tumor promotion in mice. Biol. Pharm. Bull. 2007, 30, 176-179.

19. Xu, B.J.; Chang, S.K.C. A comparative study on phenolic profiles and antioxidant activities of Legumes as affected by extraction solvents. J. Food. Sci. 2007, 72, 159-166.

20. Zainol, M.K.; Abd-Hamid, A.; Yusof, S.; Muse, R. Antioxitative activity and total phenolic compounds of leaf, root, and petiole of four accessions of Centella asiatica (L.) Urban. Food Chem. 2003, 81, 575-581.

21. Robbers, J.E.; Speedie, M.K.; Tyler, V.E. Pharmacognosy and Pharmacobiotecnology; Editora International Williams \& Wilkins: Baltimore, USA, 1996; pp. 128.

22. Zuanazzi, J.A.S. Flavonóides. In Farmacognosia: da planta ao medicamento; Simões, C.M.O., Schenkel, E.P., Gosmann, G., Mello, J.C.P., Mentz, L.A., Petrovick, P.R., Eds.; Editora UFSC: Florianópolis, Brazil, 2000; pp. 576-614.

23. Mensor, L.L.; Menezes, F.S.; Leitão, G.G.; Reis, A.S.; Santos, T.C.; Coube, C.S. Screening of Brazilian plant extracts for antioxidant activity by the use of DPPH free radical method. Phytother. Res. 2001, 15, 27-30.

24. Cao, G.; Sofic, E.; Prior, R.L. Antioxidant and prooxidant behavior of flavonoids: Structureactivity relationships. Free Rad. Biol. Med. 1997, 22, 749-760.

25. Madsen, H.L.; Nielsen, B.R.; Bertelsen, G.; Skibsted, L.H. Screening of antioxidative activity of spices. A comparison between assays based on ESR spins trapping and electrochemical measurement of oxygen consumption. Food Chem. 1996, 57, 331-337.

26. Moller, J.K.S.; Madsen, H.L.; Altonen, T.; Skibsted, L.H. Dittany (Origanum dictamnus) as a source of water-extractable antioxidants. Food Chem. 1999, 64, 215-219.

27. Subathra, M.; Shila, S.; Devi, M.A.; Panneerselvam, C. Emerging role of Centella asiatica in improving age-related neurological antioxidant status. Exp. Geronto. 2005, 40, 707-715.

28. Kamuhabwa, A.; Nshimo, C.; de Witte, P. Cytotoxicity of some medicinal plant extracts used in Tanzanian traditional medicine. J. Ethnopharmacol. 2000, 70, 143-149.

29. Fiore, G.; Nencini, C.; Cavallo, F.; Capasso, A.; Bader, A.; Giorgi, G.; Micheli, L. In vitro antiproliferative effect of six salvia species on human tumor cell lines. Phytother. Res. 2006, 20, 701-703.

30. Stewart, D.J. Mechanisms of resistance to cisplatin and carboplatin. Crit. Rev. Oncol. Hematol. 2007, 63, 12-31. 
31. Barbosa, N.R.; Pittella, F.; Gattaz, W.F. Centella asiatica water extract inhibits iPLA 2 and cPLA 2 activities in rat cerebellum. Phytomedicine 2008, 15, 896-900.

32. Association of official analytical chemists. In Official Methods of Analysis of the Association of Official Analytical Chemists, 9th ed; Board: Washington, USA, 1960; p. 275.

33. Vennat, B.; Gross, D.; Pourrat, H. Hamamelis virginiana: Identification and assay of proanthrocyanidins, phenolic acids and flavonoids in leaf extracts. Pharm. Acta Helv. 1992, 67, 11-14.

34. Sreejayan, N.; Rao, M.N.A. Free radical scavenging activity of curcuminoids. Drug Res. 1997, 46, 169-171.

35. Denizot, F.; Lang, R. Rapid colorimetric assay for cell growth and survival-modification to the tetrazolium dye procedure giving improved sensitivity and reliability. J. Immun. Meth. 1986, 89, 271-277.

36. Wallace, H.J.; Higby, D.J. Recents Results in Cancer Research: Platinum Coordination Complexes in Cancer Chemotherapy; Connors, T.A., Roberts, J.J., Eds.; Springer-Verlag: New York, NY, USA, 1974; p. 167.

37. Wiltshaw, E.; Roberts, J.J.; Carr, B. Recents Results in Cancer Research Platinum Coordination Complexes in Cancer Chemotherapy; Springer-Verlag: New York, NY, USA, 1974; p. 178.

(C) 2009 by the authors; licensee Molecular Diversity Preservation International, Basel, Switzerland. This article is an open-access article distributed under the terms and conditions of the Creative Commons Attribution license (http://creativecommons.org/licenses/by/3.0/). 